胆囊癌と十二指腸乳頭部腺腫とを併存した大腸腺腫症の 1 例

\begin{tabular}{|c|c|c|c|c|}
\hline \multicolumn{5}{|c|}{ 神戸大学医学部第 1 外科 } \\
\hline 伊藤あつ子 & 裏川 & 公章 & 熊谷 & 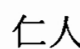 \\
\hline 安積 靖友 & 佐埜 & 勇 & 橋本 & 可成 \\
\hline 武田浩一郎 & 清水 & 道生 & 斉藤 & \\
\hline
\end{tabular}

\title{
ADENOMATOSIS COLI ASSOCIATED WITH ADENOCARCINOMA OF THE GALLBLADDER AND ADENOMA OF THE PAPILLA OF VATER
}

\author{
Atsuko ITOH, Tomoaki URAKAWA, Kimindo KUMAGAI, \\ Yasutomo AZUMI, Isamu SANO, Yoshinari HASHIMOTO, \\ Koichiro TAKEDA, Michio SHIMIZU and Yoichi SAITOH
}

The First Department of Surgery, Kobe University School of Medicine

索引用語 : 大腸腺腫症, 胆变癌, 十二指腸乳頭部腺腫

I. はじめに

近年, 大腸腺腫症に上部消化管や消化管外に高頻度 に腫瘍状病変が出現することが明らかになり，本症が 全身性の疾患であるとの概念が確立してきた ${ }^{11 \sim 4)}$. 本 症の大腸外病変としては胃, 十二指腸 polyposis, 十二 指腸乳頭部腺腫，Gardner 兆候である骨腫，軟部組織 腫瘍のほか甲状腺腫などの併存が多いとされるが5), 胆囊病変を併存したとする報告はきわめて少ない，今 回われわれは大腸に多数（約30個）の腺腫を有し，家 族歴より大腸腺腫症之考光られる症例に，胆重癌，十 二指腸乳頭部腺腫を併存した症例を経験したので報告 する.

\section{II. 症 例}

患者：62歳, 男性.

主訴：右季肋部痛.

現病歴：20歳ごろより下峲，便秘を繰り返していた が，58歳時に姉が大腸腺腫症と診断されたため呼び出 し調査を受け，大腸に多発性の polyp (約30個)を指摘 され，以後定期的に follow upを受けていた，一方40 歳ごろより年に 1 2 度右季肋部痛があったが， 1 年 前ごろより頻回に同症状が出現するようになったため 当料入入院となった.

家族歴：第 3 姉 (59歳時) が他院にて大腸腺腫症（横

$<1987$ 年12月 9 日受理>別刷請求先：伊藤あつ子 干650 神戸市中央区楠町 $7-5-2$ 神戸大学医学 部第 1 外科
図 1 家族歴

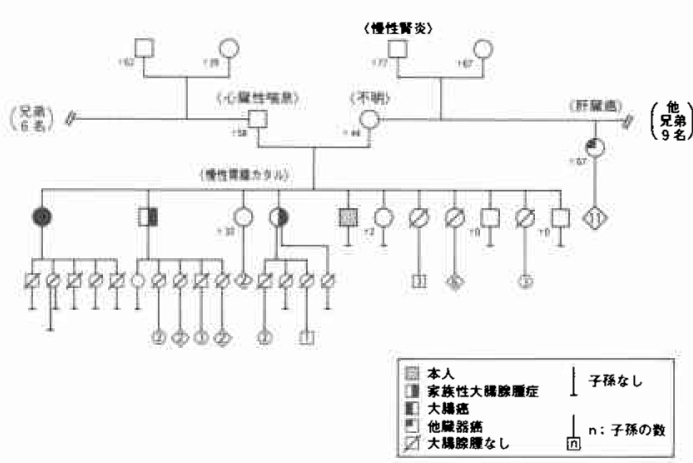

行結腸, 下行結腸に進行癌合併, 腺腫数約 160 個) 之診 断され，呼び出乙調查にて長兄 (55歳時) 長姉（63歳 時)にも大腸腺腫症を認めた(腺腫数それぞれ約 500 個, 約300個, 癌化なし). 父系, 母系についても調查され たが詳細は不明である. 次世代には現在まで大腸腺腫 症の発症はない(図 1).

入院時現症および入院時検査所見：特記すべきもの はなく, 体表の色素沈着や腫瘤形成, 骨腫, 歯牙異常 を認めず, carcinoembryonic antigen, $\alpha$-fetoprotein などの tumor marker 異常はなかった。

上部消化管透視および内視鏡所見：食道，胃に ulcer, polyp などの異常所見を認めなかった.

注腸造影 $\mathrm{X}$ 線検查および大腸内視鏡所見 : S 状結 腸，上行結腸を中心に散在性に約 30 個の有茎性一亜有 
図 2 注腸造影 X 線検査 (左), 大腸内視鏡 (右上) 和 よび大腸 polyp 組織像（右下）：山田 II ～III typeの polypで異形性の強い組織像を呈す。 (Haematoxylin-Eosin 染色, $\times 250$ )
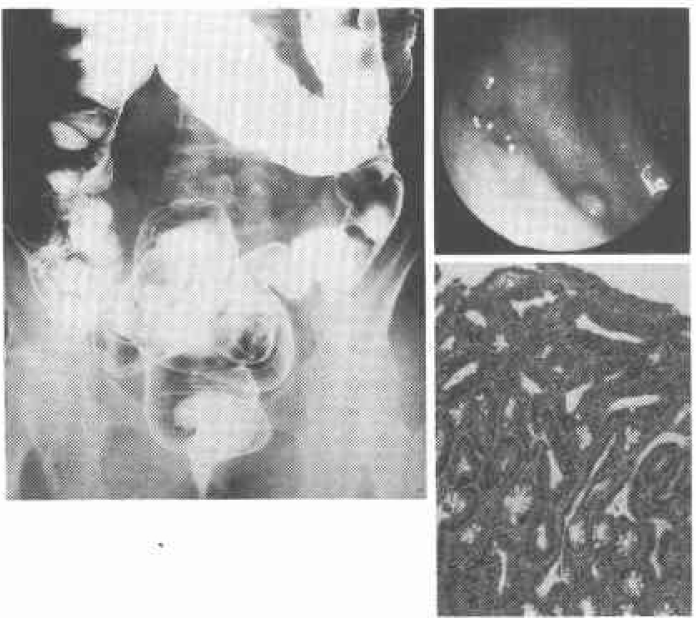

茥性の直径5 (mm) 程度の polyp を認めた。一部を内 視鏡的に切除したところ，腺管腺腫の病理組織診断を 得た。一部は図 2 に示すように粘膜内癌と表現しても 良いと思われる組織像もみられた。

Ultrasonography (以下US) 扰よび computed tomography（以下CT) 所見：US では胆囊内に不整 形あるいは茸状隆起を示す 3 個の acoustic shadow を伴わない実質性エコー像を認め，最大のものは約 $2.5 \times 2.5(\mathrm{~cm})$ であった. ほかに acoustic shadow 伴ら直径約 $5(\mathrm{~mm})$ の結石エュー像も存在した. CTで も同様の所見を得，大きさ，形状より癌を疑った（図 3 ).

Endoscopic retrograde cholangiopancreatography 所見：十二指腸乳頭部は母指頭大の腫瘤状を呈 し，前壁側側面に一部ビラン状の不整を認め，生検の 結果 adenoma と診断された。乳頭開口部は腫瘤中央 部にあった。他には十二指腸に異常はなかった。胆管 造影では総胆管に拡張はなかったが，結石を示唆する $7(\mathrm{~mm})$ の透亮像を認めた。 また胆囊内にはUS, CT と同様の腫瘤状陰影を認めた，膵管に異常はなかった (図 4).

以上より, 大腸腺腫症に併存した胆囊癌(胆石併存), 十二指腸乳頭部腺腫と診断した。この症例に対し, 胆 囊, 十二指腸病変が大腸病変より予後に強く関与する であろうこと, 患者の主訴などを考慮すると, 早期の 胆囊, 十二指腸病変の処置が先決と考方, 抎大胆囊摘

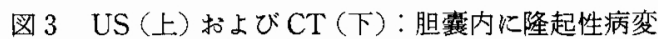
を認める。

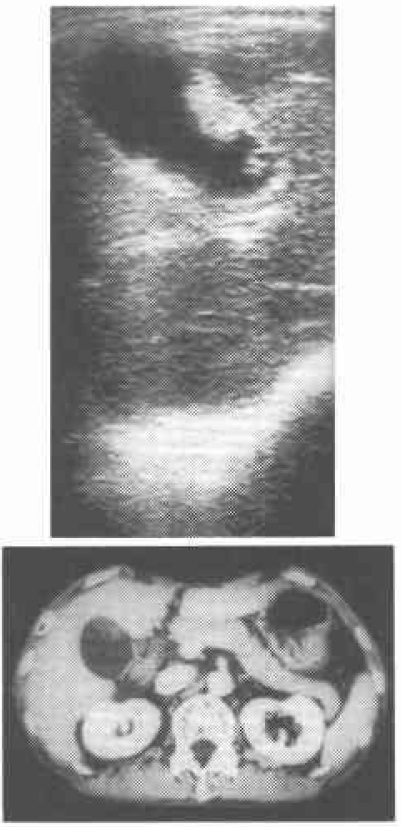

図 4 ERCP：乳頭部に一致して母指頭大腫瘤を認め （左），造影にて胆裹内，総胆管内に陰影欠損を認め る(右).
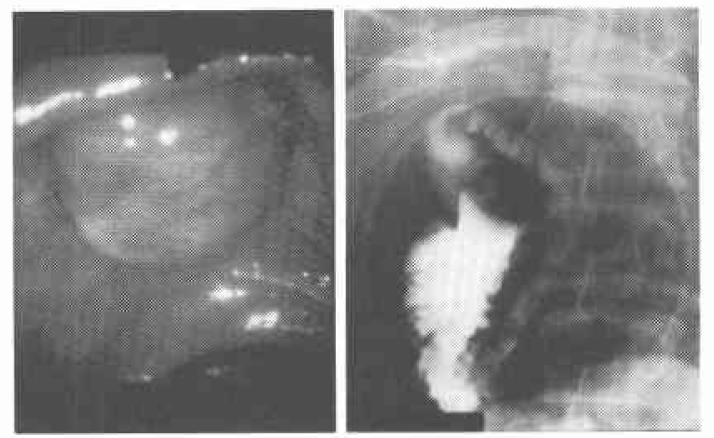

出術 (肝床部を含む胆歅摘出術), 十二指腸乳頭部切除, 十二指腸乳頭形成，総胆管切開術を施行した。

切除標本肉眼所見：胆囊体部〜頸部に 2 個の相連な る亜有茥性のカリフラワー状を呈する隆起性病変を認 あた。 大きさは $2.5 \times 2.0(\mathrm{~cm}), 3.0 \times 4.0(\mathrm{~cm})$ であっ た. 胆囊管にも同様の $1.2 \times 1.2(\mathrm{~cm})$ の腫瘤病変があっ た。腫瘤は非常にもろく出血を伴っていた(図 5)。 。 た胆囊，総胆管にそれぞれ 1 個のビリルビンカルシウ ム石が存在していた。十二指腸乳頭部は母指頭大の腫 瘤状を呈し，粘膜は浮腫状でところどころに乳頭状の 
図 5 切除胆霌標本：カリフラワー状を呈する隆起性 病変を認める。

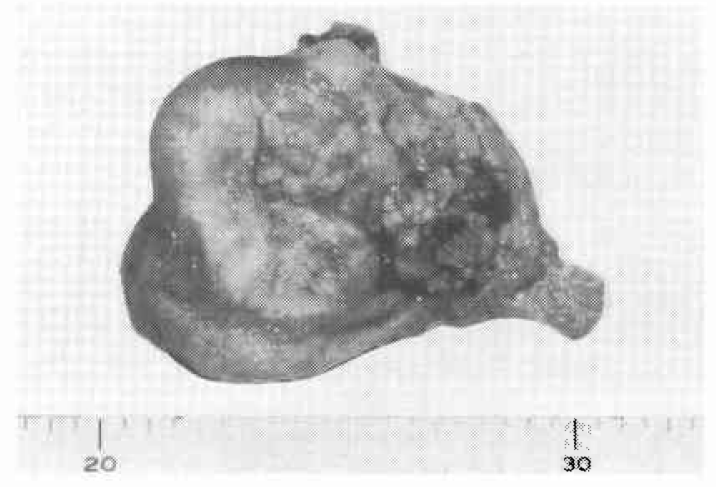

図 6 胆䧶腫瘤組織像：一部に粘膜内癌の混在した粘 膜上皮の過形性から成る組織像を呈する。 (Haematoxylin-Eosin 染色, $\times 100)$

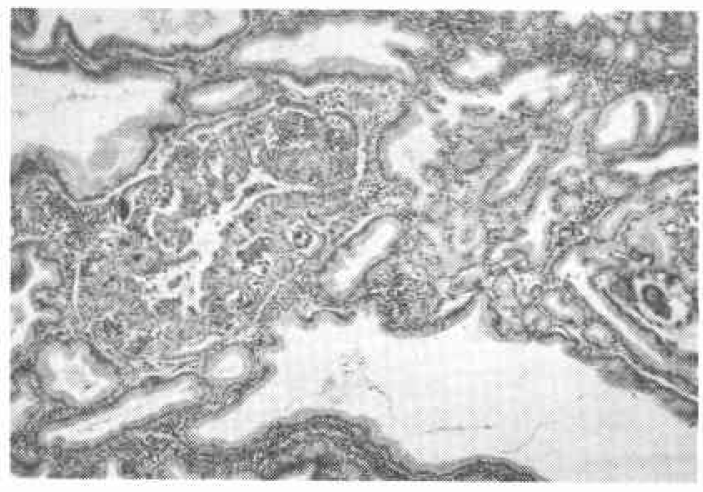

凹凸不整を認めた。

病理組織学的所見：胆囊腫瘤の組織像は大部分軽度 の異形性を有する粘膜上皮の過形成から成り，その一 部には図6で示すような粘膜内癌の混在を認めた。十 二指腸乳頭部腫瘤の組織像は中等度の異型を有する腺 管腺腫から成り (図 7)，一部には鋸歯状を呈し粘膜内 癌とも考えらる組織像を呈した.

\section{III. 考 察}

大腸腺腫症は大腸にビマン性に多数の腺腫が発生し 放置すればほぼ全例が癌化をさたす常染色体優性遺伝 の疾患である6). 腺腫の数に関して宇都宮 ${ }^{9}$ は全国調査 にて500個以下のものは非常にまれであるとし，Bussy $5^{6)}$ 女本症の多くは300 3,000個の腺腫を有し最低の ものは150個であったと報告している。一般的には 100 個以上を大腸腺腫症とし，それ以下のものは多発性大 腸 polyp として異なった範ちゅうの疾患と考克られ
図 7 乳頭部腫瘤組織像：中等度の異型を有する腺管 腺腫像を呈す. (Haematoxylin-Eosin 染色, × 100)

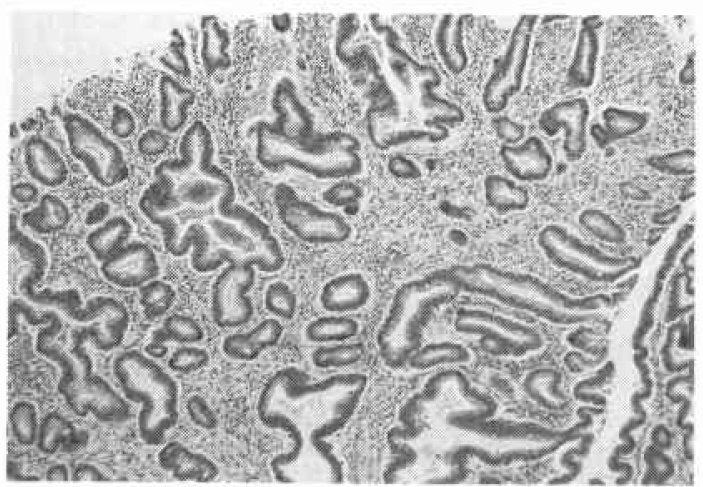

表 1 胆囊腫瘍併存大腸腺腫症報告例

\begin{tabular}{|c|c|c|c|c|c|c|c|}
\hline [i: & 報 告 者 & 年性 & 胆重病变 & 盟石 & 他の合併病变 & 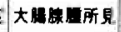 & 家族歴 \\
\hline 1 & $\begin{array}{r}\text { Burney }{ }^{21)} \\
(1976)\end{array}$ & 43 女 & 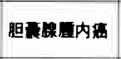 & 8 個 & 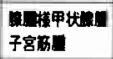 & 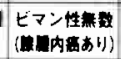 & なし \\
\hline 2 & $\begin{array}{c}\text { Tantachamurun 22: } \\
(1979)\end{array}$ & 40 男 & $\begin{array}{l}2 \text { 個 } \\
\text { adenonatous polyp }\end{array}$ & 田刓かけ & 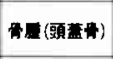 & 私200蔨 & $\begin{array}{c}\text { 子供に } \\
\text { 大触的症 }\end{array}$ \\
\hline 3 & $\begin{array}{c}\text { Akamatsu } \\
(1983)\end{array}$ & 76 女 & $\begin{array}{l}\text { 多発性polyp } \\
\text { (腺堙内亚有) }\end{array}$ & なし & なし & $\begin{array}{c}\text { 粎300個 } \\
\text { (進行点合伴) }\end{array}$ & 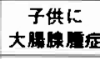 \\
\hline 4 & $\begin{array}{r}\text { Bombi 23i } \\
(1984)\end{array}$ & 71 男 & 胆 窇 & 2 個 & 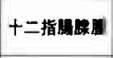 & 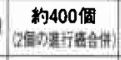 & 不明 \\
\hline 5 & 自 例 & 62 男 & 胆重楾踖内專 & 2 個 & 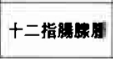 & 粎30個 & $\begin{array}{c}\text { 兄弟に } \\
\text { 大腺腺臛症 }\end{array}$ \\
\hline
\end{tabular}

ているが(6)，多発性大腸 polypの中にも家族性を示す ものがあり，遺伝形式は劣性遺伝とされるが，優性遺 伝を示したと考光られる家系や，大腸腺腫症との混在 家系の報告8)9 あある。このよらな多発性大腸 polyp 之 大腸腺腫症の異同については遺伝子レベルの病因解明 が必要と思われるが, 少なくとも一部は同一疾患の表 現形式の差によるものと考光られる、特に今回のよう に家族に明らかな大腸腺腫症が存在し, 比較的多数の 腺腫を有する例は大腸腺腫症としてさしつかえないと 考光る。一方大腸腺腫症には家族性大腸 polyposis, Gardner 症候群などが含まれるが，従来大腸 polyposis と呼ばれたものは大腸に限局した疾患と考 えられ，骨腫，軟部組織腫瘤を合併する Gardner 症候 群とは別個の疾患と考它られてきた ${ }^{1112)}$ ，乙かし本邦 を中心とする多数の研究者によって両疾患ともに上部 消化管さらに消化管外に腫瘍状病変が合併することが わかってきて扣り，両者は同一疾患として全消化管ひ いては全身性の疾患であるとの概念が確立してき た ${ }^{1) \sim 4}$. 本症の大腸外病変として胃に約 $60 \%{ }^{2) \sim 51}$, 十二 指腸に約 $90 \%$ D polyp 病変が合併するとされる。また 
十二指腸乳頭部腺腫の報告は少ないが, 生検にて約 $50 \%$ に腺腫像を認めたとの報告もあり ${ }^{12)}$ ，をた periampullary carcinoma としては比較的古くより報告 がある(3) 15). しかし本症に胆囊, 胆道系に腫瘍を併存 したとする報告は非常にまれで16) 20), 胆囊腫瘍状病変 の併存報告例は著者らの涉㧩した範用では現在までに 4 例 ${ }^{17)}$ 20) あるたずない.宇都宮ら ${ }^{21)}$ は本症を消化管 (特に大腸)に発現傾向の強い多様性腫瘍素因を有する 遺伝疾患ととらえ, 大腸に発現傾向の強い原因の 1 つ に環境要因をあげている。このことは本症患者は胆囊 にも腫瘍素因を有し, 胆石など何らかの外的要因と関 連し胆囊腫瘍を発生する可能性を示唆する。本症の腫 瘍発生機序と胆汁組成の関連性を指摘する報告もあ $\eta^{22)}$, 本症例でる胆露, 十二指腸乳頭部之胆汁通過経路 に腫瘍を発生して㧍り, 何らかの胆汁組成の変化が大 腸のみならずこれらの部位に共通の腫瘄発生要因之 なっていることも想像される.

近年のめざましいUSやCT などの診断技術の進歩 により胆囊病変はより詳細に検討され報告例も増加し ている. これに伴い本症に打ける胆囊病変併存例が増 加する可能性すあり, 今後本症においては胆囊, 胆道 系病変に十分注意する必要があると考える。また本症 例のような非典型的な大腸腺腫症についても詳細に合 併病変を検討し, 多発性大腸 polyp との異同について の解決の緒としたい.

\section{IV.おわりに}

胆変癌, 十二指腸乳頭部腺腫を併存した大腸腺腫症 と思われる症例を経験したので若干の文献的考察を加 え報告した。

\section{文献}

1) Utsunomiya J, Nakamura $T$ : The occult osteomatous changes in the mandible in patients with familial polyposis coli. Br J Surg $62: 45-51,1975$

2) Utsunomiya J, Maki T, Iwama $T$ et al: Gastric lesion of familial polyposis coli. Cancer $34: 745-754,1974$

3) Watanabe H, Enjoji M, Yao $T$ et al: Gastric lesions in familial adenomatosis coli. Hum Pathol 9:269-283, 1978

4) Ushio K, Sasagawa M, Doi $H$ et al: Lesions associated with familial polyposis coli : Studies of lesions of the stomach, duodenum, bones and teeth. Gastrointest Radiol 1:67-80, 1976

5）飯田三雄：若年者大腸ポリポーシス.この症例の 治療方針。外科 $48: 658-663,1986$

6) Bussey HJR, Veale AMO, Morson BC:
Genetics of gastrointestinal polyposis. Gastroenterology $74: 1325-1330,1978$

7）宇都宮譲二：消化管ポリポージスの臨床分類と日 本人症例の特徽。日臨 $34: 1378-1388,1976$

8) Woolf CM, Richards RC, Gardner EJ : Occasional discrete polyps of the colon and rectum showing an inherited tendency in a kindred. Cancer 8: 403-408, 1955

9) Lindberg B, Kock NG: A family with atypical colonic polyposis and gastric cancer: a three decade followup. Cancer $35: 255-259,1975$

10) McKusick VA: Genetic factors in intestinal polyposis. JAMA 182:271-277, 1962

11) DeCosse JJ, Adams MB, Condon RE : Familial polyposis. Cancer $39: 267-273,1977$

12) Iida $M$, Yao $T$, Itoh $H$ et al: Endoscopic features of adenoma of the duodenal papilla in familial polyposis of the colon. Gastrointest Endsc $27: 6-8,1981$

13) Cabot RC: Case records of the Massachusetts General Hospital : case 21061. N Engl J Med $212: 263-267,1935$

14) Harned RK, Williams SM : Familial polyposis coli and periampullary malignancy. Dis Colon Rectum 25:227-229, 1982

15）飛鋪修二, 馬場正三, 水谷謭二ほか：家族性大腸腺 腫症の術後 4 年目に発見された十二指腸乳頭部癌 の 1 例. 胃と腸 $20: 1027-1032,1985$

16) Lees CD, Hermann RE: Familial polyposis coli associated with bile duct cancer. Am J Surg $141: 378-380,1981$

17) Burney B, Assor D: Polyposis coli with adenocarcinoma associated with carcinoma in situ of the gallbladder. Am J Surg 132: $100-102,1976$

18) Tantachamrun $\mathrm{T}$, Borvonsombat $\mathrm{S}$, Theetranonat C: Gardner's syndrome associated with adenomatous polyp of gallbladder, report of a case. J Med Ass Thailand 62 : 441-446, 1979

19) Bombi JA, Rives A, Astudillo $E$ et al: Polyposis coli associated with adenocarcinoma of the gallbladder, report of a case. Cancer 53 : $2561-2563,1984$

20）赤松 信, 山木健一郎, 北川 晋ほか：胆衰ポリ ポージをを合併した家族性大腸ポリポージスの 1 例. 胃之腸 $18: 627-632,1983$

21）宇都宮譲二, 岩間毅夫, 鉿木宏文ほか：大腸ポリ ポージスの分類. 外科診療 $17 ; 235-246,1975$

22) Sachatello CR, Hedgecock H, Armstrong A: What can experimental colorectal cancer tell us about colorectal cancer in man?. Dis Colon Rectum $23: 80-85,1980$ 